\title{
セラミックスのカーボン被覆
}

\section{Carbon coating of ceramics}

\section{稲垣道夫**, 森下隆広 $*$, 豊田昌宏 ${ }^{* *}$, 津村朋樹**, 金野英隆 ${ }^{* * *}$}

Michio Inagaki**, Takahiro Morishita**, Masahiro Toyoda**, Tomoki Tsumura** and Hidetaka Konno***

\section{1. 経 緯}

1985 年以降のフラーレンとそれに続くカーボンナノチューブ についての爆発的な研究ブームに抵抗感をもっていた稲垣は,もう 1つの同素体と考えられていたカルビンを合成してみようと考え た。1995年頃であったろうか。それまでにポリ塩化ビニル (PVC) 炭素化物を標準的なコークス試料 (PV-7 と名付けていた) として用い, 黒鉛化への雲囲気, 加圧, さらに共存物の影響につい て研究を行っていた。そして, PVCの熱分解はジッパーレアクシ ヨンと呼ばれ, $\mathrm{HCl}$ がジッパーを開くようにいっせいに取れ, 直線 上のポリエン分子となること,それが非常に反応性に富み空気中 に出せば発火して燃焼することを知っていた。これこそカルビ ンであると考え, PVCを数百度に加熱した後, 液体窒素中に急冷 することによって, それを空気中に取り出せるのではないかと考 えた。しかし, 担当の学生は急冷してもまったくカーボンが得られ ないという。そこで, 詳しく聞くと, 使った真っ白なアルミナ皿 が真っ黒になるだけで, カーボン粉末はまったく得られないこと がわかった。そこで, $\mathrm{Al}_{2} \mathrm{O}_{3}$ 粉末と $\mathrm{PVC}$ 粉末を混合し加熱処理す れば, カーボン被覆 $\mathrm{Al}_{2} \mathrm{O}_{3}$ が得られるのではないかと考えた。そ こで, $\gamma-\mathrm{Al}_{2} \mathrm{O}_{3}$ を使って試してみると, 加熱処理するだけで, 真っ

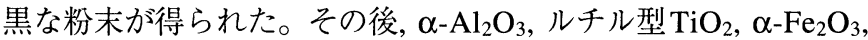
そして $\mathrm{MgO}$ などの酸化物セラミックスの粉末を用いて同様の処 理を行い,カーボン被覆ができることを確認した。

稲垣は, 簡単な操作でカーボン被覆ができ, 粉末状でサンプル が得られるのは大変拉もしろいと考え, アメリカでのCarbon Conference で報告するとともに, J. European Ceramic Societyへ論 文を発表した1)。しかし，当人が意気込むほど反響は得られなか った。その後は,酸化鉄を使うと還元されて鉄となることに興味を もち, 鉄, ニッケルなどが黑鉛化触媒であることから, 低温での黒 鉛化を検討する方向に進んだ (4.5参照)。

一方, 奈良高専の泉先生がアナターゼ型 $\mathrm{TiO}_{2}$ にこの手法でカ 一ボン被覆することができ, その光触媒能も損なわれないことを 発表された2)。この研究を共著者の豊田 (当時, 福井高専), 津村
(当時, 株ナード研究所) が引き継ぎ,多くの研究を行った (4.1 参 照)。それらの研究は最近の可視光に対しても活性な酸化チタン および酸化タングステン還元相の作製に結びついた (4.2参照)。 また, 日本瓦がセラミックスの下地にカーボンを蒸着させている ことから, 瓦の新しい作製法とならないか, 瓦の産地である愛知 県常滑市にある愛知県常滑敜業技術センターの竹内氏と共同研 究を行った (4.4参照)。一方, 共著者の金野はアルミニウム表面 に形成した $\mathrm{Al}_{2} \mathrm{O}_{3}$ 酸化膜を利用してカーボン被覆によるアルミニ ウムの耐食性の向上を目指した研究を行った (4.5 参照)。そし て, その研究は酸化アルミニウムの微細孔を利用したカーボンナ， ロッドの作製研究に繋がった (4.6参照)。

他方このようにして生成したカーボンは多孔質であると考えら れ,カーボン被覆アナターゼ光触媒についての議論では, 被覆し たカーボンによる吸着能を議論した。そして，その際にカーボン 被覆 $\mathrm{TiO}_{2}$ について測定された見掛けの表面積と被覆カーボン量 (高温での燃焼隇量から正確に測定できる) から, 基材の $\mathrm{TiO}_{2}$ の 表面積をゼロと仮定して,カーボン層の表面積を計算した。この 結果は $1000 \mathrm{~m}^{2} / \mathrm{g}$ を超える値を与えることが多く，なかなか審査 員を説得することが難しかった。そこで, 実際にカーボンを単離し てその細孔構造を測ってみることとし, 基材として $\mathrm{MgO}$ を選ん だ。 $\mathrm{MgO}$ を選んた最大の理由は希硫酸で簡単に溶解, 除去でき ることであった。この研究は, 大学院の博士課程に進学した共著 者の森下 (現在, 東洋炭素(秼))が中心となって行い, 酢酸, クエン 酸マグネシウムなどの塩を用いること, $\mathrm{MgO}$ をリサイクルできる ことを実験的に示すとともに，このようにして作製した多孔炭の電 気二重層キャパシタへの応用の研究を行った (4.3 参照)。さら に, $\mathrm{MgO}$ を共存させることによって, 還元で生じた金属 $\mathrm{Sn}$ を微粒 子で分散させ得ることを見出し,リチウムイオン二次電池負極材 としての用途を開発した 4.8 参照)。

本稿では, セラミックスのカーボン被覆が簡単に行い得ることを 説明した後, 各種のセラミックス粒子へカーボン被覆をした実例を 用途との関連で説明することによってその利点を示した。

* Corresponding Author, E-mail: ina@aitech.ac.jp

(平成 18年7月 10 日受理, 平成 18 年7月26日採択)

* 愛知工業大学工学部: ₹470-0392 豊田市八草町八千草8121

* Faculty of Engineering, Aichi Institute of Technology : 8121 Yachigusa, Yakusa, Toyota 470-0392, Japan

** 大分大学工学部：干 870-1192 大分市旦野原800

** Faculty of Engineering, Oita University : 800 Dannoharu, Oita 870-1192, Japan

***北海道大学大学院工学研究科 : $=060-8628$ 札幌市北区北13条西8

***Graduate School of Engineering, Hokkaido University : Kita-ku, Sapporo, Hokkaido 060-8628, Japan 


\section{2. カーボン被覆法}

セラミックス粉末あるいはブロックをカーボン被覆するプロセ スはきわめて簡単で, 炭素前駆体とセラミックス基材を混合し, 不活性雲囲気中で $1000{ }^{\circ} \mathrm{C}$ 前後の温度まで加熱することによって 行われる。その基本プロセスを図 1 として示した。

炭素前駆体は熱可塑性であることが必須であり，いずれも粉末 として用いている。ペットボトルの再利用を念頭にそれを小片 に切って用いたこともあるが, 粉末の場合と違いは認められなかっ た。現在までに使用したことのある前駆体をその略号と一緒に 図1中に示した。また, セラミックスとしては, 各種酸化物の粉 末および酸化マグネシウムを低温で生成する酢酸マグネシウム あるいはクエン酸マグネシウムなど, そして日本瓦の原料である セラミック素地のタイルおよび表面が酸化アルミニウムとなって いるアルミニウム板などが用いられた（図1）。

このセラミックスと炭素前駆体が粉末の場合, 両者を乳鉢中で 軽く混合して用いるが, 必ずしもそのことが必須ではなく,2つの 粉末を層状に堆積させた状態でもよい。この時炭素前駆体を上 部に置くほうが可塑性となった熱分解物が確実にセラミックス 粉末に浸透した。また，セラミックスタイルを用いた場合は，炭 素前駆体粉末を下に敷いた状態で加熱処理しても, タイル上面ま でカーボン被覆できたが, 炭素前駆体熱分解物が上昇し得る高さ には限界があると考えられる。セラミックスの表面性状もカー ボン被覆に対して重要であり, 表面が非常に平滑な場合, 例えば 溶融して作られたあるいは施釉してあるセラミックスなどは, 本 法ではカーボン被覆が困難であり，一見被覆されているように見え ても剥がれやすい。

加熱処理は不活性䨌囲気中で行うことが必須条件であり, 不活 性ガスとしてアルゴンを用いるか, 窒素を用いるかで差が認めら れたのは,ルチル型 $\mathrm{TiO}_{2}$ の還元相 $\mathrm{Ti}_{\mathrm{n}} \mathrm{O}_{2 \mathrm{n}-1}$ を作製した場合のみ である。この $\mathrm{Ti}_{n} \mathrm{O}_{2 \mathrm{n}-1}$ 相の合成においては雾囲気中の酸素量が 重要な影響を与えている。また, カーボン被覆したアナターゼ型
$\mathrm{TiO}_{2}$ を $900{ }^{\circ} \mathrm{C}$ 以上の温度で作製した場合, 室温まで泠却した後に 急激に空気中に取り出すと, 発熱してカーボンが燃焼する現象が 認められた。これはアナターゼ型 $\mathrm{TiO}_{2}$ 粒子の極表面が還元され ていることに原因していると考えられる。

このプロセスによって作製されるものはカーボン被覆セラミッ クスであり,多くの場合にその状態で機能を発揮すると期待され る。例えば, 光触媒能と吸着能のハイブリッド化を目的としたカ 一ボン被覆アナターゼの作製であり, 耐食性向上を目指したアル ミニウム板のカーボン被覆などが挙げられる。さらに, 基材とな った $\mathrm{MgO}$ を溶解, 除去することによって多孔質炭素として分離 することも可能である。また, 被覆した多孔質なカーボン層にさら に第三成分を添加することも可能であり, 金属鉄や白金微粒子を 担持することも容易である。

カーボン被覆セラミックスの生成過程を知るためにDTA-TG 解析を行った。図2に3つの場合の結果を示した。

図2a）は酢酸マグネシウムとPVAの場合である。酢酸マグネ シウムは $250^{\circ} \mathrm{C}$ 以下で熱分解 $\mathrm{MgO}$ 微粒子を生じる。その $\mathrm{MgO}$ 粒子は $300{ }^{\circ} \mathrm{C}$ 前後でPVA から生じた可塑性の熱分解物によって 被覆される。被覆された熱分解物は $\mathrm{MgO}$ との需れがよく, その 粒子表面に付着して流動が困難となる。その状態で炭素化が進 むために多孔質となると考えられる。この $\mathrm{MgO}$ 粒子を溶解, 除 去することによって, $\mathrm{MgO}$ 粒子とほほ同じ大きさの細孔を得るこ とができる。図3a）は, $100 \mathrm{~nm}$ 程度の粒子径をもつ $\mathrm{MgO}$ と PVA の混合物を炭素化し, $\mathrm{MgO}$ を溶解, 除去したもので, $100 \mathrm{~nm}$ 程度 の細孔が認められる。

図2b）は酸化鉄 $\mathrm{Fe}_{3} \mathrm{O}_{4}$ と PVCの混合物の場合である。PVCの 熱分解が $300{ }^{\circ} \mathrm{C}$ 前後で生じ, 酸化鉄粒子がその可塑性熱分解物で 覆われる。その後, 酸化鉄と熱分解物が反応し金属鉄が生成す る。この還元反応が被覆後に生じるために, 図3b）に示したよj に, 金属鉄はカーボンの殻の中に存在する。基材のセラミックスが 炭素前駆体の熱分解物と反応しなければ, 図 $3 \mathrm{c})$ に $\alpha-\mathrm{Al}_{2} \mathrm{O}_{3}$ につ いて示したように, 基材の粒子形態を保った状態でカーボン被覆

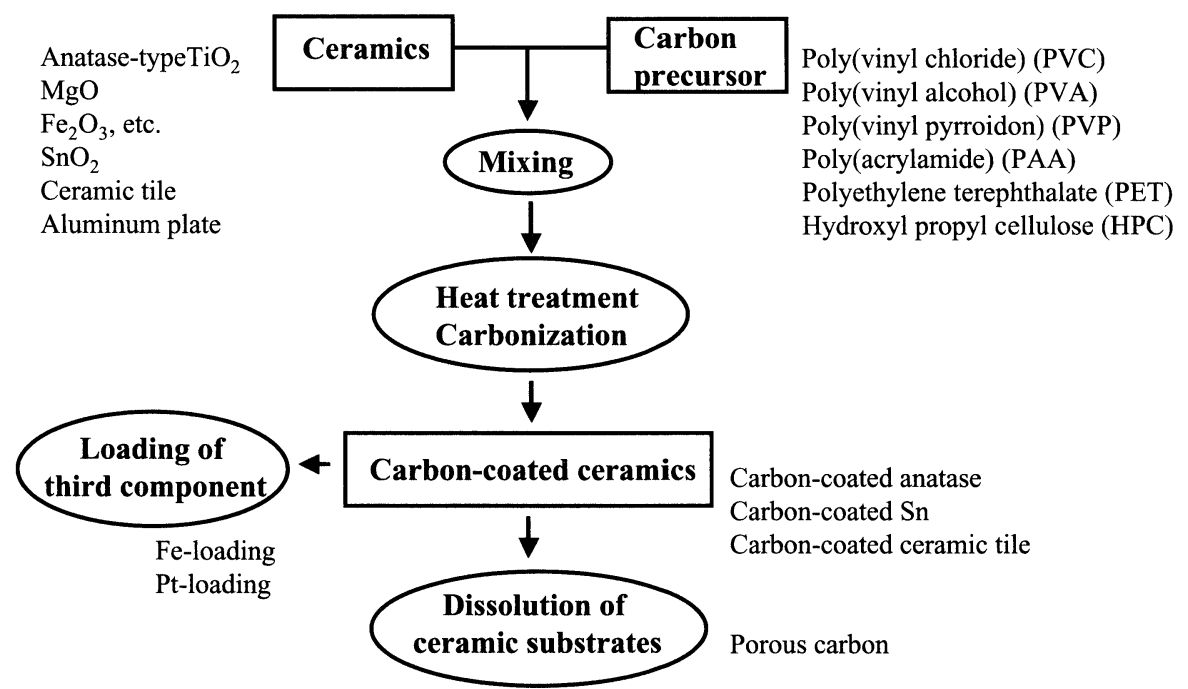

図1 カーボン被覆のためのプロセスと今までに使用した前駆体 
a) Mixtures of $\mathrm{MgO}$ precursor with PVA

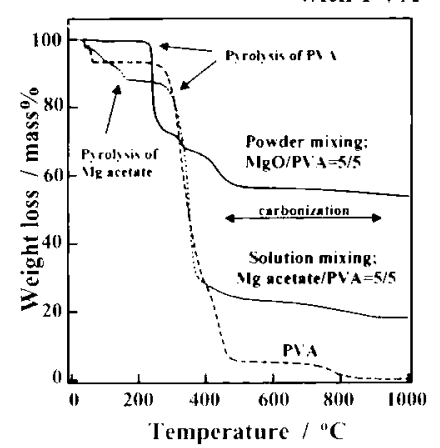

b) $\mathrm{Fe}_{3} \mathrm{O}_{4} / \mathrm{PVC}=5 / 5$ mixture

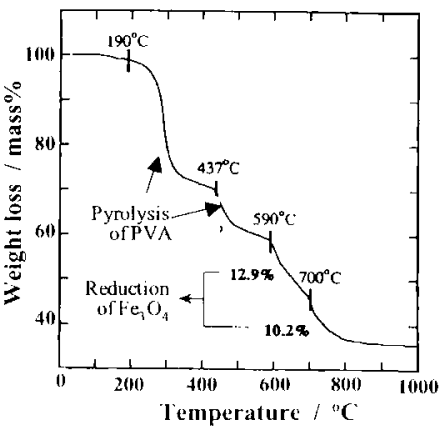

c) Mixture of para-ammoniumu

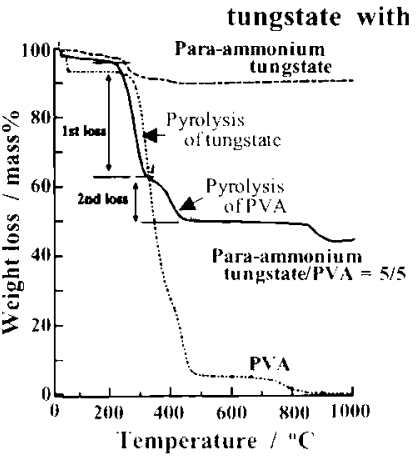

図2 七ラミックス
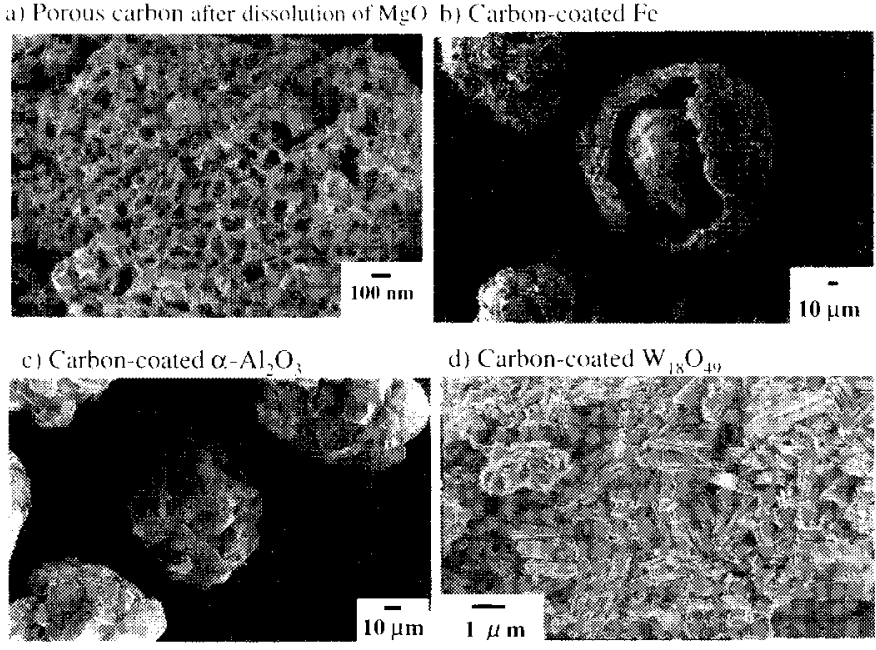

d) Carbon-coated $\mathrm{W}_{18} \mathrm{O}_{4}$

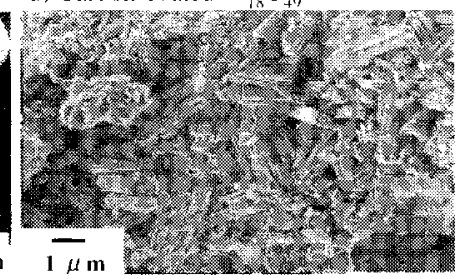

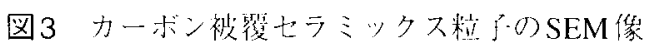

当札る。

図2c)はバラアンモニウムタングステン洒とPVAの湜合物の

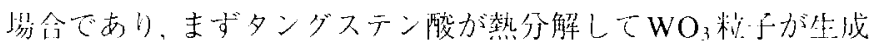
し、PVAの熱分㬨物によって被覆さ扎，その後雨者が反応して

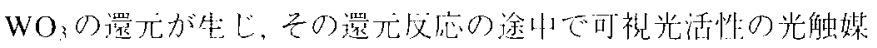
であるカーボン被覆 $\mathrm{W}_{18} \mathrm{O}_{40}$ 在生成与名(図3d)

七ラミックス粉末の量に対して渦剩のカーボン前駆体老北之 なけ狄ば、得られた力ーボン被覆七ラミックスは粉末しして得ら れることも眮味梁い。しかし，カーボンによって凝集体となるか どうかはセラミックスの状態とカーボン前駆体からの崖素化仪率 に強く低存吉る。しかし，凝集している場命の多くは，䊖子同士 がカーボンを介してつながっているため, 簡単にほぐすことがで きる。

\section{3. 本法の特徴と適用のための要件}

セラミックスのカーボン被覆にはいくつかの方法が杽いられて いるが，本法の特徴はそのプロセスの簡単さ，簡便さにあるとい えよう。セラミックスあるいはその前駆体と炭素前駆体を接触 させた状態で, 不活性雲囲気中で加熱処理することによってカー ボン被覆がなされる。特殊な装置を必要とせず, 不活性ガス中で 加熱処理が可能な電気炉と試料を入れるルツボさえあれば可能

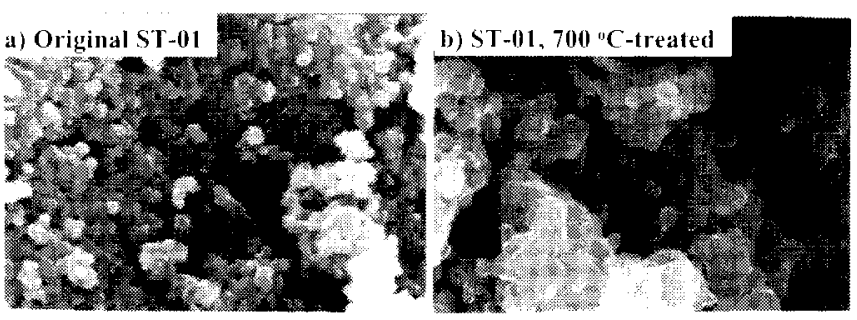

c) $\mathrm{ST}-01 / \mathrm{PV} \mathrm{A}=0.5 / 9.5,700$ "C-treated d) $\mathrm{ST}-01 / \mathrm{PV} \mathrm{A}_{\mathrm{S}}=5 / 5,700$ "C-treated

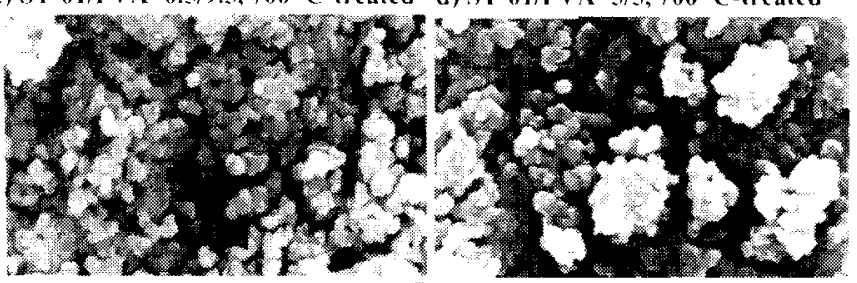

e) $\mathrm{ST}-01 / \mathrm{PVA}=9 / 1,9000^{\circ} \mathrm{C}$-treated $\mathrm{OST}-01 / \mathrm{PVA}=5 / 5,900{ }^{\circ} \mathrm{C}$-treated

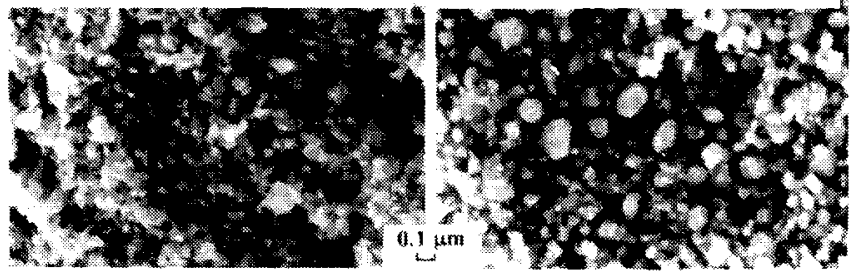

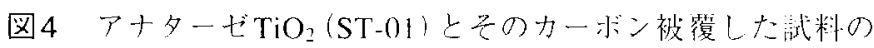
SEM 像

である。

しかし，目们とする㤔料在本法で命成するたかには，いくつか

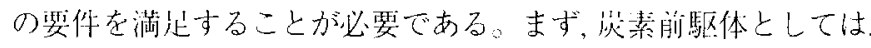
図2に関速して記したように，熱可塑性であることが必須条件で

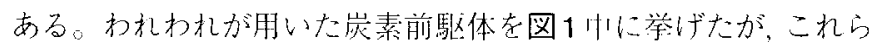
に限るものではない。本法の開発はPVCを使って始めたが，塩 素の関与は望ましくないので，現住は使鬥していない。また，七 ラミックスを微精子で得たい場全はその前駆体加ら出発するこ とが推奖される。しかし，その前駆体からのセラミック又数子が， 炭素前駆体の熟分解が生じる以解生成していることが必要で ある。クエン酸マグネシウムを $\mathrm{MgO}$ 前駆体として使うことによ つて $5 \mathrm{~nm}$ 程度の $\mathrm{MgO}$ 粰于力得ら扎，その溶酷，除去によって約 $5 \mathrm{~nm}$ の徍をもつメソポーラスカーボンが合成できた。また，2つ の前駆体混合方法も七ラミックス粒子の大きさに大きな影響を 
与え，ひいてはその機能を支配する。パラアンモニウムタングス テン酸を $\mathrm{WO}_{3}$ 前駆体としてPVA と水溶液を使って混合すること によって微粒子の $\mathrm{W}_{18} \mathrm{O}_{49}$ を合成でき(図3c), その可視光活性が 実現できた。

図3b）～d）に示したように, カーボン被覆によって, $1000{ }^{\circ} \mathrm{C}$ 付近 の高温まで加熱しても, セラミックス粒子の焼結, 粒成長が抑制 されることは, 本法のもう1つの特徵であろう。図4に $\mathrm{TiO}_{2}$ の場合 を示した。約 $7 \mathrm{~nm}$ の一次粒子が凝集して $60 \mathrm{~nm}$ 程度の大きさの 粒子を形成している市販アナターゼ $\mathrm{TiO}_{2}$ (ST-01) 光触媒 (図 4a) を $700{ }^{\circ} \mathrm{C}$ に加熱すると,粒子同士が焼結して, 大きな結晶粒子とな る (図4b) と同時に半分ぐらいがルチル型に転移する。しかし， ST-01/PVA 比が $0.5 / 9.5$ および5/5の混合物を 700 および $900{ }^{\circ} \mathrm{Cに}$ 加熱処理することによってカーボン被覆したものは, 原料ST-01 の粒子の大きさがほぼ保たれているとともに, アナターゼ型の結 晶構造を保っている (図 $4 \mathrm{c} \sim \mathrm{f})$ 。

\section{4. カーボン被覆技術の適用例}

\section{1 カーボン被覆光触媒アナターゼ}

アナターゼ型結晶構造をもつ $\mathrm{TiO}_{2}$ に, その本来の特性である光 触媒能に加えて吸着能をもたせることができればと, ヒドロキシ アパタイト, 活性炭などへの酸化チタンの担持などの多くの試みが なされた3)-6)。その試みの1つとして, 本法によるアナターゼの

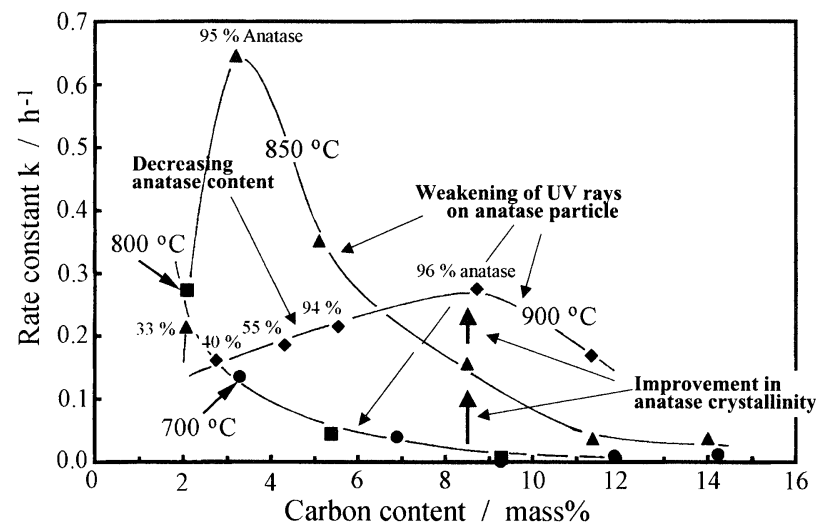

図5カーボン被覆アナターゼについてのメチレンブルーの光分 解速度定数 $\mathrm{k}$ のカーボン含有量および加熱処理温度依存性
カーボン被覆がなされた7)-18)。

図5に水中のメチレンブルーの分解速度定数 $\mathrm{k}$ をカーボン被覆 アナターゼ光触媒のカーボン被覆量に対してプロットした。カ ーボン被覆量が増加するとともに,カーボン層が厚くなると考えら れ，それによって基材であるアナターゼ $\mathrm{TiO}_{2}$ に到達する紫外光は 弱くなり, カーボン被覆を 700 および $800{ }^{\circ} \mathrm{C} て ゙$ 行った場合は, 徐々

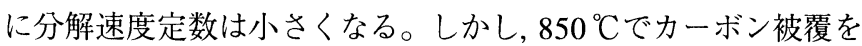
行った場合はカーボン被覆量が4mass \%付近で極大值を示す。こ れは $850{ }^{\circ} \mathrm{C} へ の$ 加熱処理によってカーボン被覆が行われると同時 に,アナターゼの結晶性が向上するために光触媒能が向上したた めである。しかし, それと同時に低カーボン被覆量領域では速度定 数が急激に減少する。これは, カーボン被覆による相転移の抑制 が十分に行われないために, アナターゼ相の一部がルチル相へ転

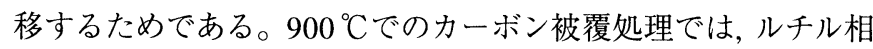
への転移がさらに促進されるため, 速度定数 $\mathrm{k}$ の極大值が高力ー ボン被覆量側にシフトしている。

カーボン被覆アナターゼの光触媒能の発現に対しては, いくつ かのプロセスを考慮しなければならない。分解したい污染物質 はいったん多孔質なカーボン層に吸着され,カーボン層中を拡散し て光触媒 $\mathrm{TiO}_{2}$ 粒子表面に達する。したがって, カーボン層が污 染物質を吸着する能力も重要な因子である。図6は700および $900{ }^{\circ} \mathrm{C}$ カーボン被覆光触媒の 4 種のモデル污染物質に対する分解 速度定数 $\mathrm{k}$ と吸着能の対応関係を示したもので, 大量に吸着される 污染物質ほど分解が早いことを示している。

白金ナノ粒子担持により $\mathrm{TiO}_{2}$ の光触媒活性向上と可視光活性 の付与が報告されているが,われわれも白金ナノ粒子を担持したチ タニアナノチューブをカーボン被覆することにより，この効果が 得られることを確認している。また, カーボン被覆 $\mathrm{TiO}_{2}$ 光触媒 に酸化鉄粒子を担持させることにより, 過酸化水素存在下, フォ トーフェントン反応が，フェノールの分解に有効に働くことを見出 し, 被覆されたカーボン層への酸化鉄粒子の担持が容易であると ともに, 光触媒能の改良にも有効であることを見出した ${ }^{19) 。 ~}$

\section{2 カーボン被覆による酸化物還元相の作製}

4.1のアナターゼへのカーボン被覆の研究過程で, 出発原料に ルチル型の $\mathrm{TiO}_{2}$ を用いた場合に還元相であるマグネリ相 $\mathrm{Ti}_{\mathrm{n}} \mathrm{O}_{2 \mathrm{n}-1}$ $(4 \leqq \mathrm{n} \leqq 10)$ が生成し得ることが見出された20)-22)。 a) $700^{\circ} \mathrm{C}$-treated

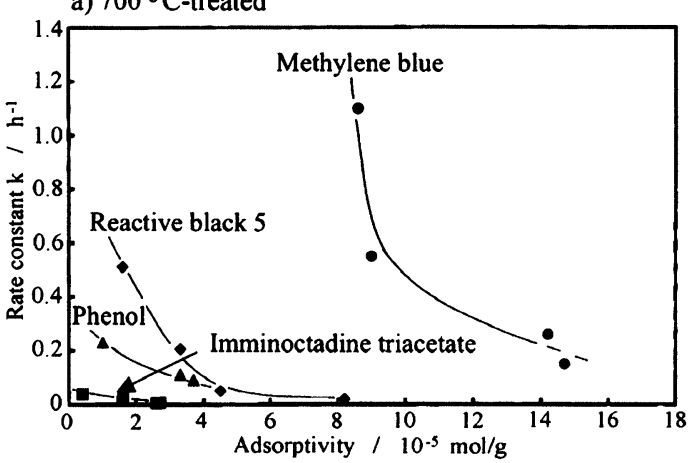

b) $900^{\circ} \mathrm{C}$-treated

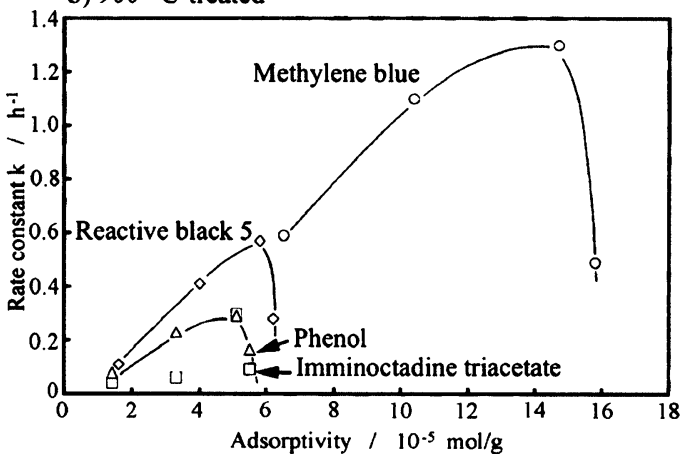

図6 カーボン被覆アナターゼについての4種の污染物質の光分解速度定数 $\mathrm{k}$ と吸着能との関係 
図7にルチル型 $\mathrm{TiO}_{2}$ (TTO-55N，石原産業製）とPVAを重量 比で $5 / 5$ の比率で混合し $, 700,800,900,1000,1100{ }^{\circ} \mathrm{C}$ で焼成した ときの粉末XRDパターン変化を示した。ルチル相が $900{ }^{\circ} \mathrm{C}$ 以上

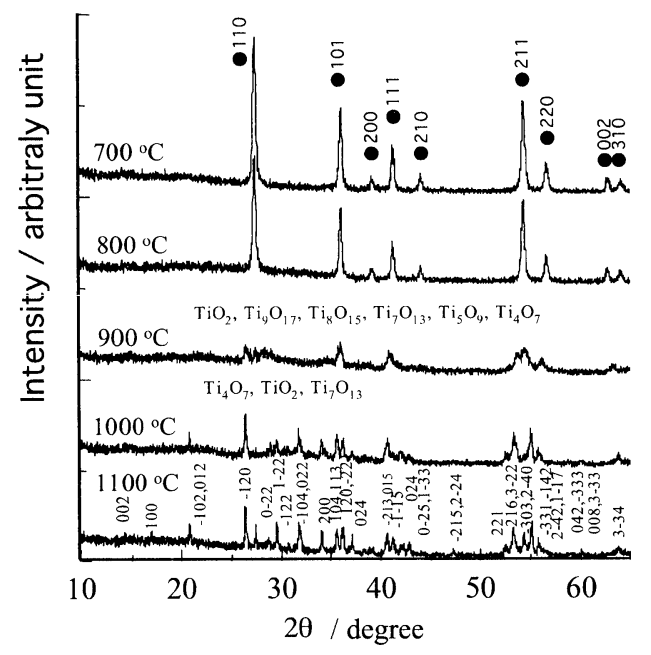

図7ルチル型 $\mathrm{TiO}_{2}$ と PVA との混合物の加熱処理温度に伴う $X$ 線回折図形変化 $\left(\mathrm{TiO}_{2} / \mathrm{PVA}=5 / 5\right)$

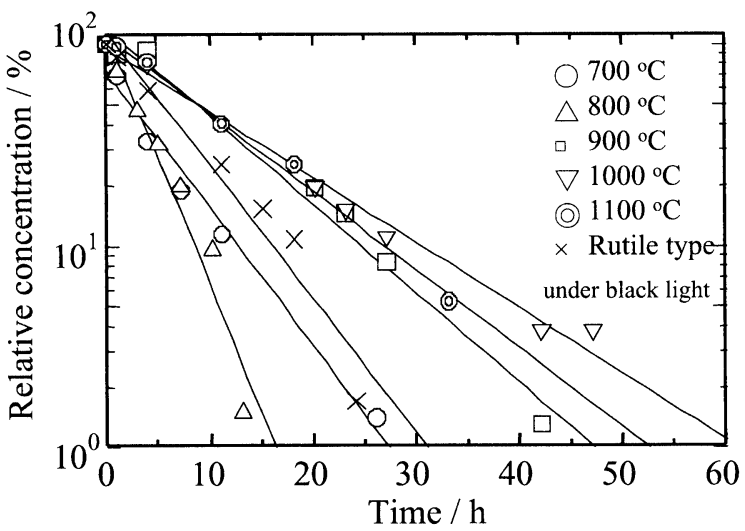

図8 カーボン被覆マグネリ相による紫外線照射下でのメチレ ンブルー溶液の退色挙動

a) Decomposition of methylene blue

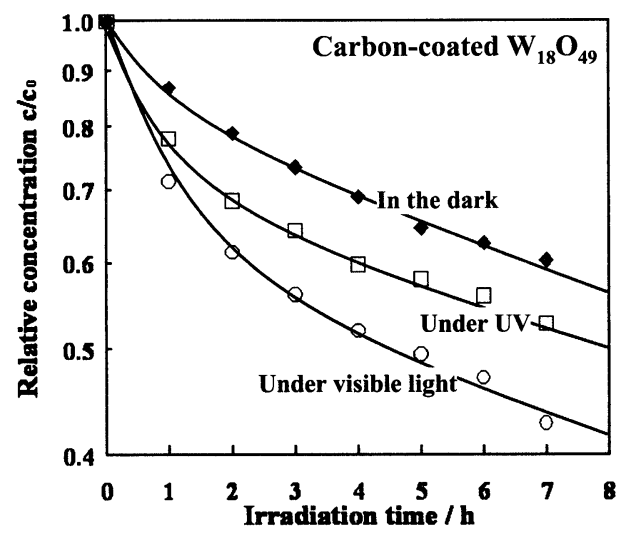

の温度で消滅しており, 新たに $\mathrm{Ti}_{\mathrm{n}} \mathrm{O}_{2 \mathrm{n}-1}(4 \leqq \mathrm{n} \leqq 10)$ が生成して いる。このように $\mathrm{TiO}_{2}$ の還元は $900{ }^{\circ} \mathrm{C}$ 付近から進行し, 処理温度 が高くなるに従い, 還元の程度が強くなり, 最終的に $1100{ }^{\circ} \mathrm{C} ゙$ て $\mathrm{Ti}_{4} \mathrm{O}_{7}$ まで還元されていることがわかる。さらに, 炭素化過程に おいて窒素ガス中の酸素を完全に除去する (チタン金属などの酸 素捕捉剤による) とさらに還元の進んだ $\mathrm{Ti}_{3} \mathrm{O}_{5}$ や $\mathrm{Ti}_{2} \mathrm{O}_{3}$ を得るこ とも可能である。

図8にカーボン被覆マグネリ相の紫外線照射下におけるメチレ ンブルーの退色実験結果を示す。出発原料のルチル相, $700,800{ }^{\circ} \mathrm{C}$ 処理サンプルよりも退色速度は小さいが, マグネリ相は明らかに 光触媒能を有していることがわかる。マグネリ相の可視光活性 についても確認しているが, 結晶相による活性の差は確認されてい ない。

メチレンブルー以外の分解例としてイミノクタジン三酢酸塩 を用いた分解実験を行っており, 同様に可視光活性を確認して いる。

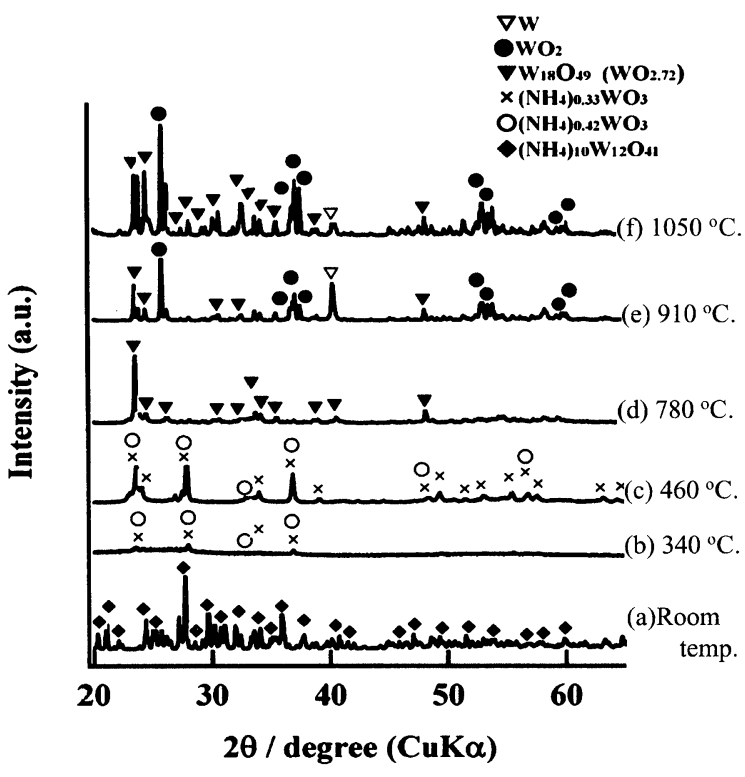

図9 X 線回折図形から見た $\mathrm{W}_{18} \mathrm{O}_{49}$ の生成過程

b) Decomposition of phenol

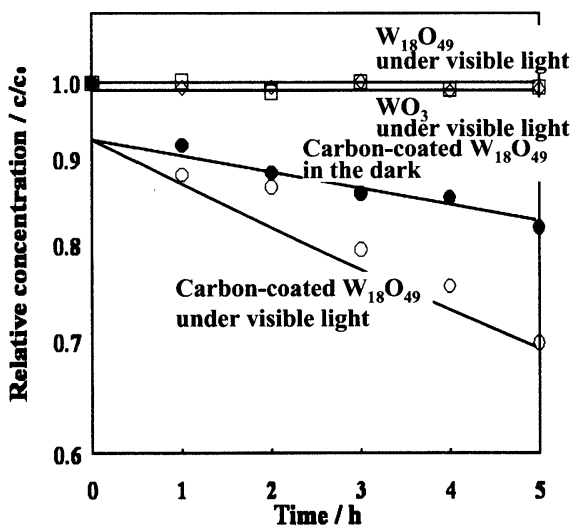

図 10 カーボン被覆 $\mathrm{W}_{18} \mathrm{O}_{49}$ およびその関連試料によるメチレンブルーおよびフェノールの分解挙動 
パラアンモニウムタングステン酸とPVAをそれぞれの溶液と した後, 混合, 乾燥, 加熱処理することによってカーボン被覆 $\mathrm{W}_{18} \mathrm{O}_{49}$ が作られた。図9は混合物を種々の温度で加熱処理した ものの $\mathrm{X}$ 線回折図形を示したものであり, $800{ }^{\circ} \mathrm{C}$ 付近の温度で $\mathrm{W}_{18} \mathrm{O}_{49}$ が生成している。このカーボン被覆 $\mathrm{W}_{18} \mathrm{O}_{49}$ について, 可 視光下で光触媒能が認められた23), 24)。図10にメチレンブルー およびフェノールの分解挙動を, ほかの試料と比較して示した。

図 10a）に拈いて,カーボン被覆 $\mathrm{W}_{18} \mathrm{O}_{49}$ は暗所でもメチレンブ ルー濃度が減少し, 吸着が進んでいることを示している。しかし， 紫外光照射下ではより急速に濃度が減少し, 可視光下でさらに急 速に分解している。 $\mathrm{W}_{18} \mathrm{O}_{49}$ は $\mathrm{WO}_{3}$ を還元雲囲気で $900{ }^{\circ} \mathrm{C} に$ 加熱 することによって作製できるが，それはフェノールに対してはま ったく活性を示さない。これに対してカーボン被覆 $\mathrm{W}_{18} \mathrm{O}_{49}$ は, 可 視光下で顕著な濃度減少, すなわち分解を示す (図10b)。カーボ ン被覆 $\mathrm{W}_{18} \mathrm{O}_{49}$ がフェノールの吸着を示すこと(“in the dark” 参照) から, 被覆されたカーボン層にフェノールが吸着されて $\mathrm{W}_{18} \mathrm{O}_{49}$ 粒 子の周囲のフェノール濃度が高くなることによって光分解能が 顕著に認められたと考えられる。

\section{3 熱可塑性前駆体からのポーラスカーボンの作製}

酸化マグネシウム $\mathrm{MgO}$ は高温まで安定であるうえ, 弱酸性水 溶液に簡単に溶解する。そこで, いったんカーボン被覆 $\mathrm{MgO}$ を 作製した後, $\mathrm{MgO}$ を酸で溶解, 除去することによって, ポーラス カーボンが得られることを見出した25)-30)。

約 $100 \mathrm{~nm}$ の大きさをもつ $\mathrm{MgO}$ 粉末と 3 種のカーボン前駆体を 種々の割合で混合し, $900{ }^{\circ} \mathrm{C}$ 炭素化した後, $\mathrm{MgO}$ を希硫酸で溶 解, 除去してカーボンを得た。そのBET 表面積を混合比の関数 として図11a）に示した。賦活に相当する処理を通っていないに もかかわらず, $1000 \mathrm{~m}^{2} / \mathrm{g}$ に達する表面積が得られる。PVAから 作ったカーボンはミクロ孔に富み, PETおよびHPCからのカーボ ンはメソポーラスであった。図11b) は, $\mathrm{MgO}$ 前駆体として酢酸 マグネシウムを用いた場合であり, PVA と水溶液として混合した 場合と粉末で混合した場合では, 表面積に大きな違いがあり, 前

a) Effect of carbon precursors

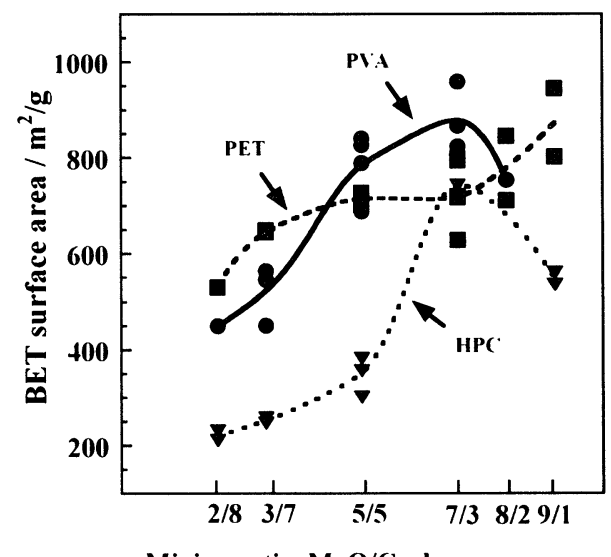

Nixing ratio, $\mathrm{NgO/Carbon} \mathrm{precursor}$
者では $1800 \mathrm{~m}^{2} / \mathrm{g}$ にまで達する。

ナノオーダーの粒子径の $\mathrm{MgO}$ を用いることによって, その抜 けた後にほぼ同じ大きさの細孔を得ることができる。図12は 種々の $\mathrm{MgO}$ 前駆体と PVAの混合物の炭素化そして $\mathrm{MgO}$ の溶解, 除去によって得られたカーボンの細孔径分布曲線を比較した。

約 $100 \mathrm{~nm}$ の大きさの $\mathrm{MgO}$ 粉末を用いた場合は, その後に残っ た細孔は100nm 前後の大きさであり (図3 参照), 図12の細孔径 分布曲線の範囲からはずれており, $2 \mathrm{~nm}$ 以下のミクロ孔のみが認 められる。酢酸マグネシウムをPVA と粉末で混合した場合には, 広い分布をもつメソ孔が生成するのに対して, 溶液で混合した場 合には $12 \mathrm{~nm}$ 付近に細孔径が集中している。また，クエン酸マグ ネシウムとすることによって細孔径分布はさらに鋭く，しかも小 さな径となる。

\section{4 セラミックスタイルのカーボン被覆}

日本瓦はセラミックスタイルの表面に炭化水素ガスの気相熱 分解によってカーボンを蒸着させている。本法を用いることに

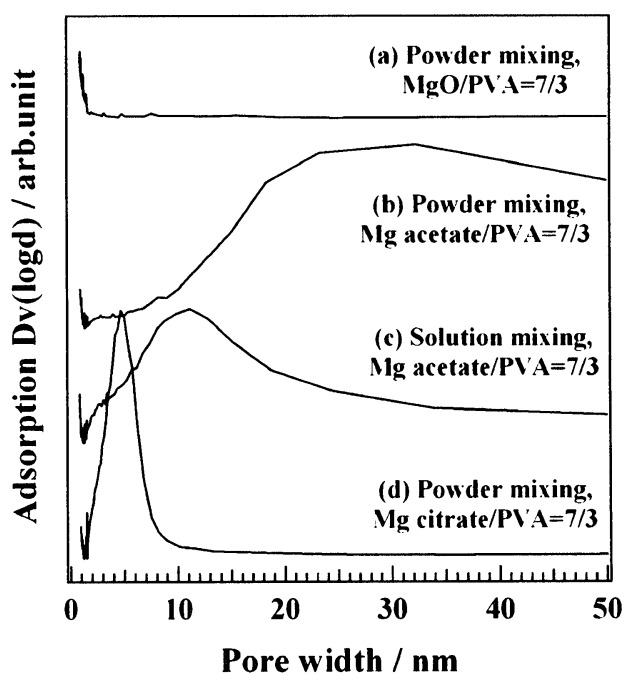

図 $12 \mathrm{MgO}$ 共存下でPVAから生成したポーラスカーボンの 細孔径分布

b) Effect of mixing methods

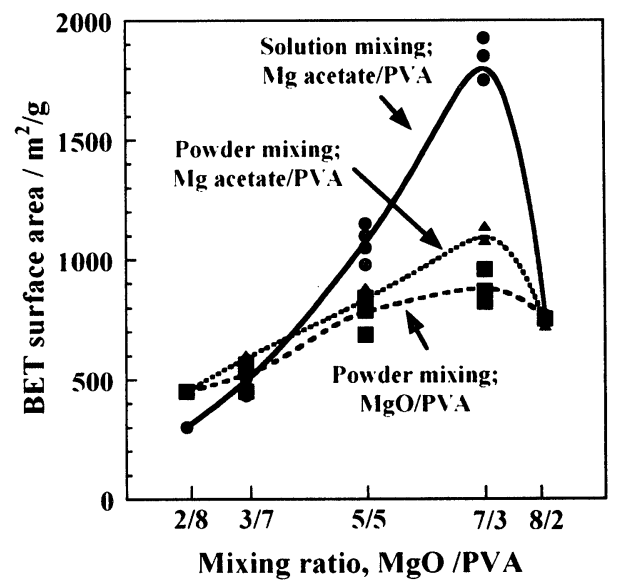

図11 酸化マグネシウムおよび酢酸マグネシウムとカーボン前駆体の混合物から作製されたポーラスカーボンにおけるBET 表面積の 混合比と混合方法への依存性 


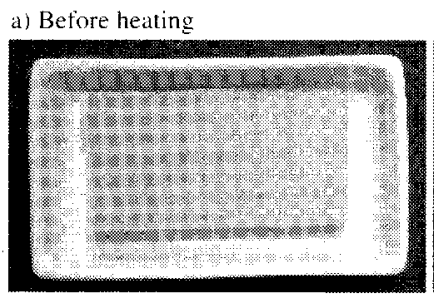

b) After heating
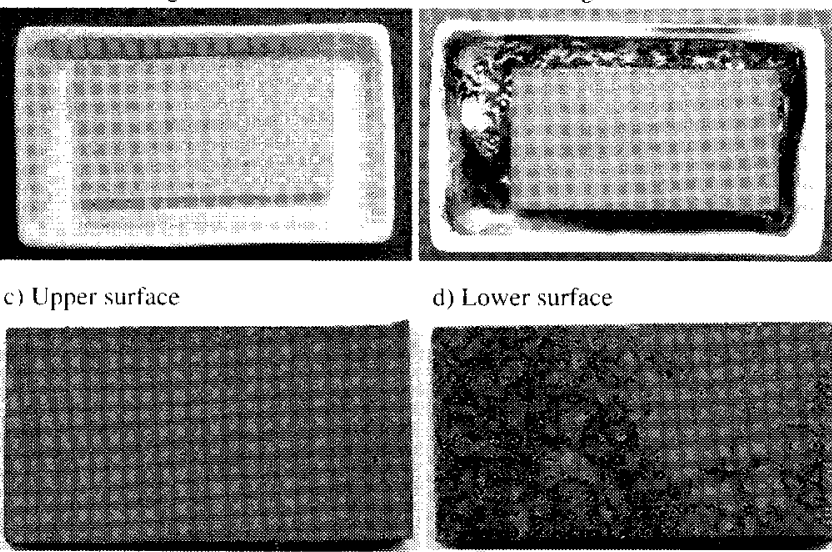

図13 セラミックス素地へのカーボン被覆

よって同様のカーボン被覆が可能であることが玄されたい!。

図13に，カードン前駆体 (PVAあるいはPET) 粉末をタイル $(35 \mathrm{~mm} \times 20 \mathrm{~mm}$ ，厚さ $4 \mathrm{~mm})$ の下に敷いた状態(図13a)で $1000^{\circ} \mathrm{C}$ 付近に加熱処理すると，直接力ーボン前駆体と接していない夕イ ル上面までカーボン被覆さ机る(図13b)。タイル上面は余分な カーボンの付着もなく、均質である(図13c)が,カーボン前駆体に 接していた下面には余分のカーボンの付着加認められた(図13d)。 しかし、これも簡単に取り除くことができ、上面と変わらない均 質なカーボン被覆ができた。

図13で示したように,カーボン前駆体からの熱分解物は夕イ 儿の側面に沿って上昇し，上面老均一にカーボン被覆する。しか し、タイルが厚すぎると上面を完全にカーボン被覆することがで きず、熱分解物の上昇高さに限度があると考之られた。

日本瓦の場合，銀白色を呈することが好まれ，そ机はグラファ イトが生成するためであるといわれ，夕イル素地中に鉄分在混在さ せることによって作られている(「燻し瓦」と呼ばれる)。他方， 本法で酸化鉄のカーボン被蕧交行うと金属鉄が生成し，その触媒 作用によってグラファイトが生成することが明らかになっている (4.7参照)。そこで, 酸化鉄をカーボン前駆体に加え, 図 13a)の 配置で加熱処理を行った。その色相を分光光度計を用いて評佂 したが、明度が必ずしも市販の櫄し瓦に相当する值には達しなか った。今後さらに検討が必要である。

\section{5 アルミニウムのカーボン被覆}

アルミニウムは腐食しやすいので，通常の目的には、アノード 酸化によって表面に多孔質皮膜を形成したのち，高温水蒸気や沸 騰水印処理 (封孔と呼ぶ)して用いる。皮膜は擬似ベーマイト 上よばれる無定型アルミナであり，中性領域では安定で耐食性も 良いが, 酸・アルカリには弱く塗装などが必要である。また，皮 膜のヴィッカース硬度は300－450程度で機械的にはあまり強く ない。カーボン皮膜は耐薬品性に優れており, 高い硬度も期待で きることから、本法によってカーボン被覆を行った。

硫酸などの水溶液中でアルミニウムをアノード酸化すると, 素地 に対して注は重直な細孔をもつ多孔質皮膜が生成する。細孔の 直径(数十一数百 $\mathrm{nm}$ ) は電解電压に比例し，厚さは笔解時間で氿

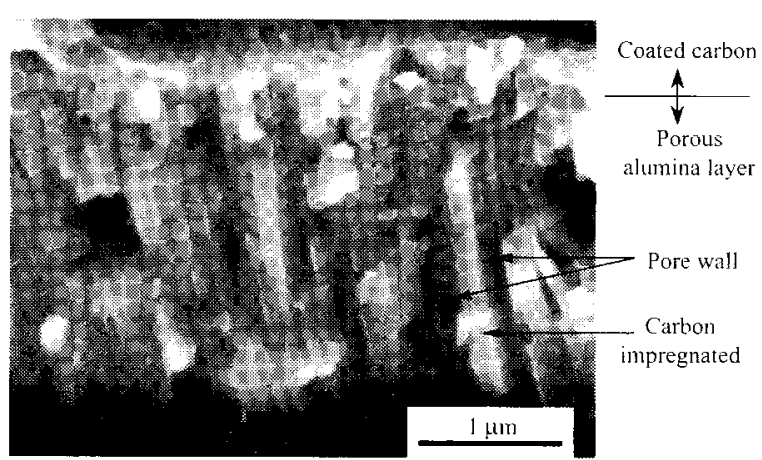

図14 カーボン被覆アルミニウム板の表面付近の断面 SEM像。液 体窒素中で破断のため被覆の・部は失われている。
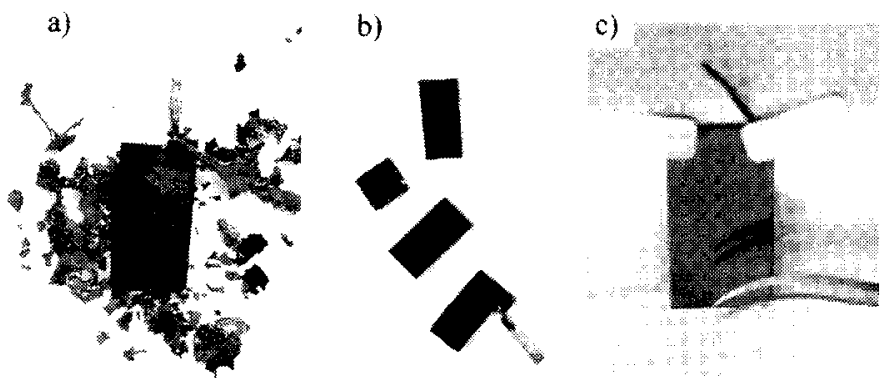

図15 カーボン被覆アルミニウム板の外観。(a) ボートから取り 出した直㣪，(b) シェアで切断したもの（c）鏡のように ピンセットの先端の陰が归暸に装っている例。

まる。このようにして酸化膜を生成させたアルミニウム板をPVA 中 に埋为，不活性雲冊気中 $300{ }^{\circ} \mathrm{C}$ 付近に0.5一 Ih 保持した後450 $550^{\circ} \mathrm{C}$ で $1 \mathrm{~h}$ 程度熱処理した。図14のようにピッチ状の炭素化物 が細孔内に浸入してアンカーとなり、カーボン被覆ができる321.331。 良好な力ーボン被覆を形成するためには，最終熱処理温度に応し て、素地の多孔質皮膜の膜厚と多孔度老適切な範网に設定する必 要がある。

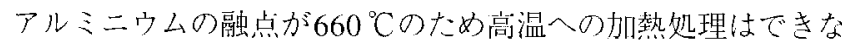
いが、図15a）に示したように被覆されなかった力ーボンは破研。 除去できる。被覆の密着性は非常に良く、全体をシェアで切断し ても剥離しない(図15b)。アルミニウム材の表伯をあらかじめ 研磨して抢くと鏡のように斗滑な黒色被覆を形成できる(図15c)。 カーボン被覆後の表面ヴィッカース硬度は，600-850と著しく 问上する。塩酸や酸性 $\mathrm{NaCl}$ 溶液中での耐食性も们上し, 被蕧膜 はアセトンやへキ开ンにも溶解しない。

\section{6 カーボンナノロッドの作製}

アノード酸化したままの多孔質酸化膜をテンプレートとして， 4.5 と同様の手法でカーボンナノロッドが作製できることを明ら

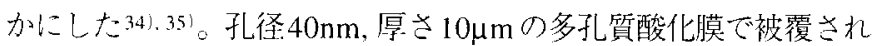
たアルミニウムフォイル上に $0.1 \mathrm{~g} / \mathrm{cm}^{2} の$ 割合でPVC粉末をのせ， アルゴン霝囲気中 $300^{\circ} \mathrm{Cで} 30 \mathrm{~min}$ 保持した後, $600^{\circ} \mathrm{C}$ で1h熱処理し た。10\% NaOH 溶液中で酸化膜を溶解・除去した後, $1500{ }^{\circ} \mathrm{C}$ で

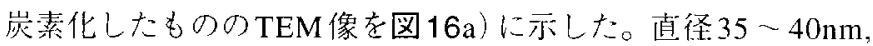

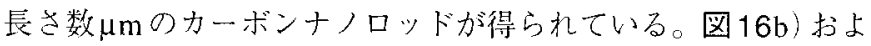




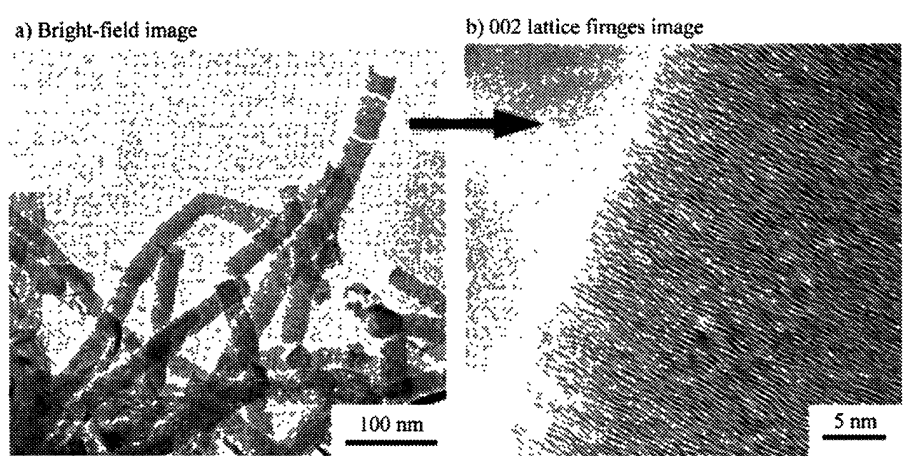

c) Selected-area electron diffraction pattern

図16 カーボンナノロッドの透過電子顕微鏡像

び図 16c）から,ナノロッド全体がプレートレット構造になって いることがわかる。 $2800{ }^{\circ} \mathrm{C}$ 処理するとこの構造を保ったままグ ラファイト化する。

このようなナノロッドは, PVA, PAAなどほかのポリマーを用 いても作製できる。多孔質酸化膜は親水性であり, 有機物に近い 分解生成物が何故このような細孔の奥まで充填されるのか, 現在 のところよくわからない。しかし，この現象はさらに複雑な形状 のテンプレートでも起きることがわかっている。径が400〜 $500 \mathrm{~nm}$ 程度のロッド状カーボンから直径数 $10 \mathrm{~nm}$, 長さ数 $100 \mathrm{~nm}$ のひげ状カーボンが無数に生えた試験管ブラシ状のカーボンナノ ロッドが得られている。この場合もひげ状部分はプレートレッ ト構造になる。

なお, 多孔質アノード酸化アルミナ皮膜を使ったフィルターが市 販されており，これも利用できるが, 使い捨てにできるほど安価 ではない。

\section{7 遷移金属酸化物を用いたグラファイトの生成}

$\mathrm{Fe}, \mathrm{Ni}, \mathrm{Co}$ などの遷移金属酸化物を用いると, カーボン前駆体 の炭素化と同時に還元されて金属となる。還元によって生成し た金属は非常に活性であり,カーボンの黒鉛化触媒として働き, $1000{ }^{\circ} \mathrm{C}$ 付近の低温でもグラファイト結晶を生成することが見出 された36)-39)。図17に, $\mathrm{NiO} / \mathrm{PVA}=4 / 6$ 混合物を $1000 \sim 1100{ }^{\circ} \mathrm{C}$ に種々の時間加熱処理したもののX 線粉末図形を示した。1000 ${ }^{\circ} \mathrm{C}$ での処理時間が 1 時間では, なお二次元的な 11 回折線しか認めら れないのに対して, 5 時間保持ではブロードではあるが三次元的 なグラファイト構造に由来する 112 回折線が認められ, 処理時間の 経過とともに成長している。加熱処理温度を $1100{ }^{\circ} \mathrm{C}$ とること によって004回折線はシャープとなり, 112 回折線も明確となる。

図 18 に, $\mathrm{Fe}_{3} \mathrm{O}_{4} / \mathrm{PVP}=7 / 3$ 混合物から $1200{ }^{\circ} \mathrm{C}$ に加熱処理して 得られたグラファイト粒子の高分解能透過電子顕微鏡像を示した。 100 暗視野像ではモワレ縞が観察され (図 18a), 制限視野回折で はスポット状の六回対称性の002 回折線が(図 18b), そして002 格子像では平行に積層した大きな網平面が認められる (図18c)。 これらの結果は高い結晶性をもつグラファイト結晶が生成して いることを示している。

$\mathrm{Fe}_{3} \mathrm{O}_{4}$ あるいは $\mathrm{Fe}_{2} \mathrm{O}_{3}$ を用いた場合にはすでに $900{ }^{\circ} \mathrm{C} て ゙$ 黒鉛結 晶の生成が認められるのに対して, $\mathrm{NiO}$ を用いた場合には $1000{ }^{\circ} \mathrm{C}$ で長時間の加熱処理を必要とした。このようなグラファイト生

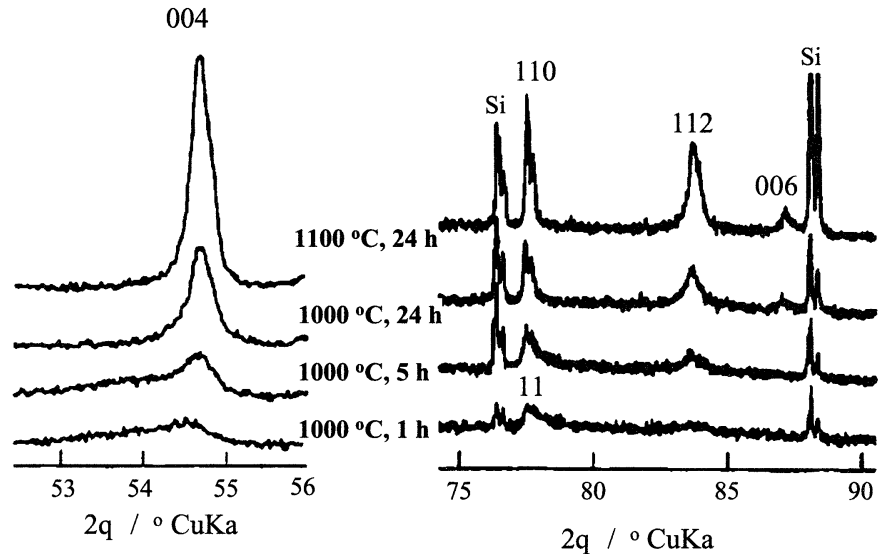

図17 NiO/PVA混合物を種々の条件下で加熱処理して得たカー ボンのX線回折図形

成の温度が異なることは, 各金属の触媒効果のメカニズムの違い によるものと考えられる。

\section{8 低融点金属微粒子の炭素中への分散}

金属スズはリチウムイオン二次電池の負極材として大きな理 論容量をもつことから, それを黒鉛中に微粒子で分散することが 試みられている。本法を酸化スズ $\mathrm{SnO}_{2}$ と $\mathrm{MgO}$ およびPVA の混 合物に適用することによって, $\mathrm{Sn}$ 微粒子を $\mathrm{MgO}$ を取り去った後 の細孔中に保持することに成功した40)。

$\mathrm{SnO}_{2}$ はPVAの炭素化過程で還元され金属となるが, 溶融状態 であるため, $\mathrm{MgO}$ 粒子がないと流動, 合体して大きな粒子となり, カーボン被覆もされない。しかし, $\mathrm{MgO}$ が共存すると, 溶融スズ が $\mathrm{MgO}$ に濡れ, 流動が妨げられるとともに, $\mathrm{MgO}$ と一緒にカー ボン被覆される。室温に冷却後, $\mathrm{MgO}$ を $1 \mathrm{M} \mathrm{HCl}$ によって溶解, 除去すると, 微粒の金属スズと $\mathrm{MgO}$ が抜け出た後の空間がカー ボンの殼の中に残る。この空間がスズ粒子と隣り合って存在する ことは, 電池負極として用いた場合にリチウムとの合金化によって 生じるスズ粒子の著しい体積膨張を吸収する役目をもっている。

図 19a)に $\mathrm{MgO} / \mathrm{SnO}_{2}=5 / 5$ として得た試料の TEM 像を示し た。 $\mathrm{Sn}$ 粒子の大きさは $\mathrm{MgO} / \mathrm{SnO}_{2}$ 比に依存し, 比が大きくなる ほど金属 Sn粒子は小さくなる。図19b）には，リチウムイオン二 次電池の負極材として使用した場合の充放電サイクルに伴う可 逆容量およびクーロン効率の変化を示した。 $\mathrm{MgO} / \mathrm{SnO}_{2}$ 比が小 

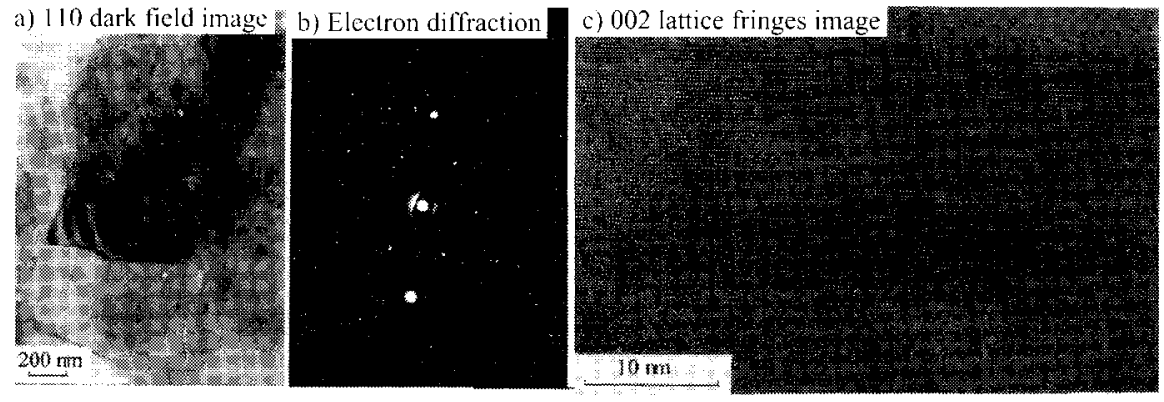

$\mathrm{Fe}_{3} \mathrm{O}_{4} / \mathrm{PVP}=30 / 70$, at $1200^{\circ} \mathrm{C}$ for $5 \mathrm{~h}$

図18 $\quad \mathrm{Fe}_{3} \mathrm{O}_{4} / \mathrm{PVP}$ 混合物から生成したダラファイト結晶の透過電子顕微鏡像

a) TEM image of carbon-coated Sn

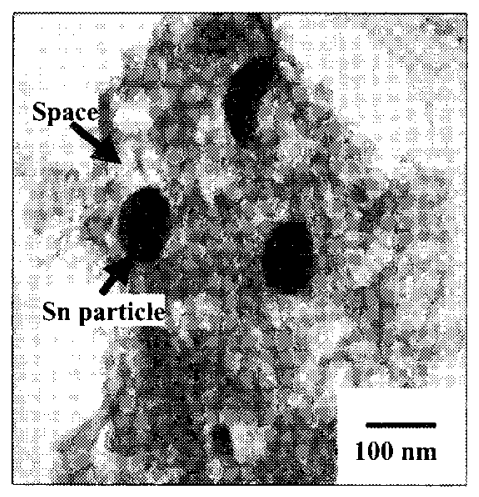

b) Cyclic performance

in Li-ion secondary battery

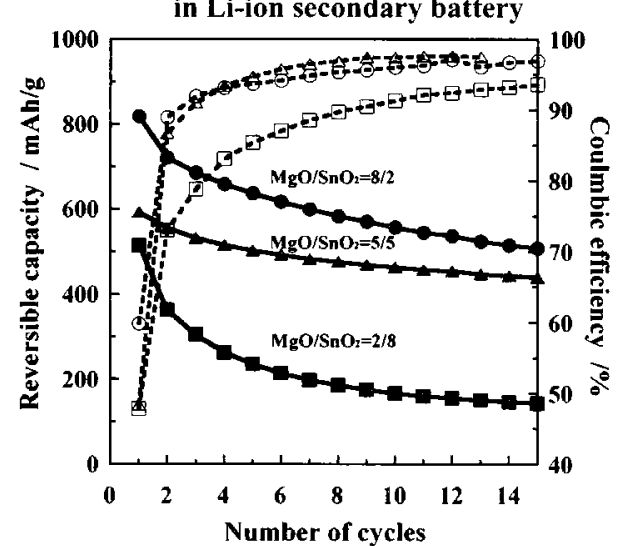

図19 カーボン被覆スズの透過電子顕微鏡像とそれをアノードとしたリチゥムイオン二次電池の充放電サイクル特性

a) Discharge-charge curves

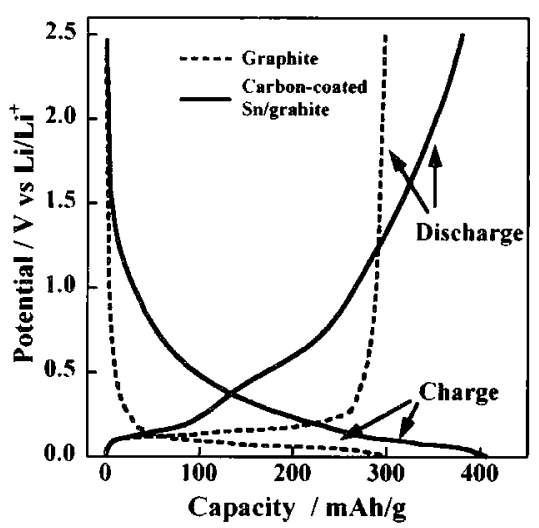

b) Cyclic performance

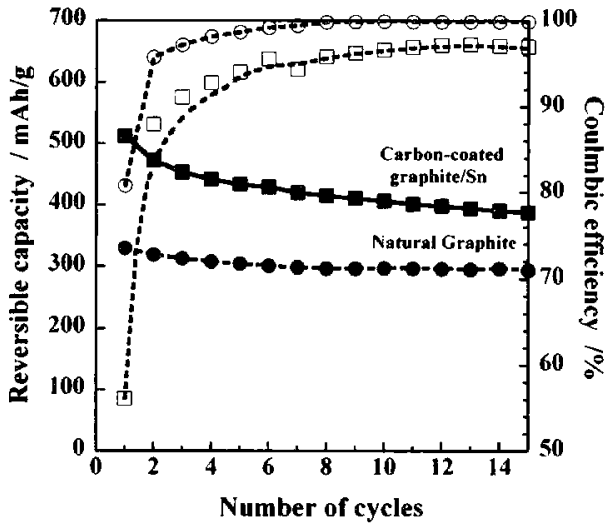

図20 カーボン被覆スズと天然黒鉛の複合材の充放電曲線とサイクル特性

さくなるほど可逆容量は大きくなり, $500 \mathrm{mAh} / \mathrm{g}$ 以上となる。ま たターロン效率も $100 \%$ に近い。

図20にカカーボン被覆Snをグラファイト共存下で作製したも のの升イクル制吽を、グラファイトのみを用いた場合と比較した。 カーボン被複 Sn 在グラファイトに担持することによって, 可近容 量を大きくするこよが可能であり，その开イクルも安定している。

\section{5. 結 言}

セラミックスの荻素被㠅技術は, セラミックスのもつ特性とカー
ボンのもつ性能を複合化することが可能であるのみでなく, 新し い機能も発揮させ得る可能性を秘めている。その展開の状況老 図21にまとめた。ここに示したものは，今までにわれわれのグ ループで取り扱ったもののみであり，コらに新しい展開があり得 ると考えている。

従来行ってきた展開の中で, $\mathrm{MgO}$ 前駆体を使った多孔質炭素 の調製は, 基材セラミックスを取り除いてしまうという点で, ほ かの技術と異なっている。しかし，ポーラスカーボンの調製法と してはまったく新しい方法であり，工業化への可能性も十分もっ 


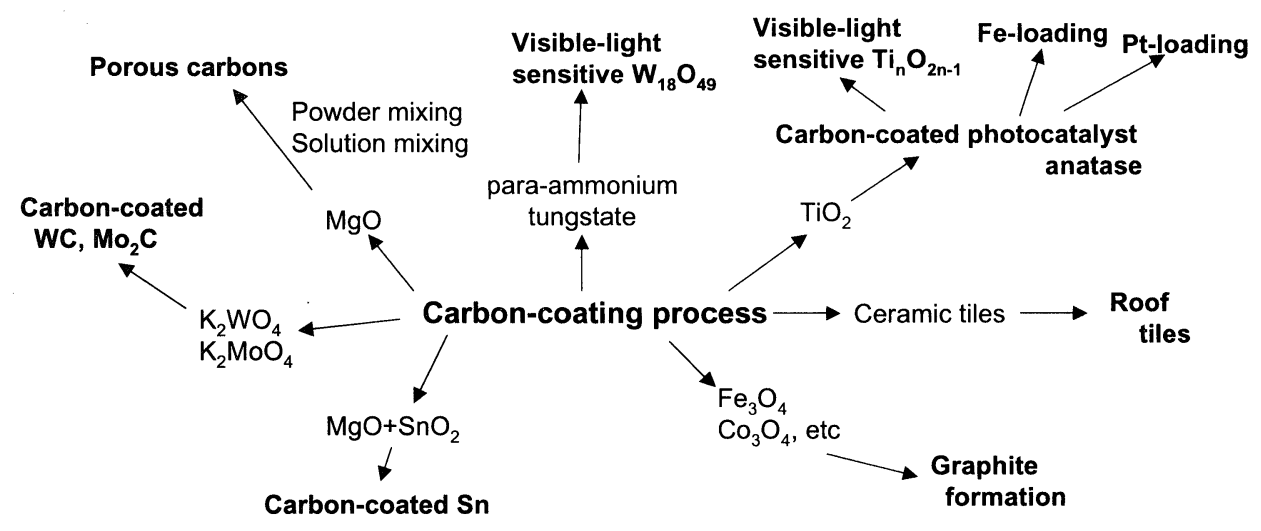

図21 カーボン被覆技術の展開

ていると考えられる。本稿では, この項目に十分のスペースを割く ことができなかったが, 別に総説としてまとめている41)のでご参 照頂きたい。

\section{文 献}

1) M. Inagaki, H. Miura and H. Konno, J. Europ. Ceram. Soc. 18 (1998) 1011-1015

2) I. Izumi, K. Kuroda, Y. Ohnishi, T. Tsumura and N. Iwashita, Mizushori Gizyutu 42 (2001) 461-465.

3) T. Torimoto, Y. Okawa, N. Takeda and H. Yoneyama, J. Photochem. Photobio. A: Chem. 103 (1997) 153-157.

4) M. Harada, A. Tani, H. Yamashita and M. Anpo, Z. Phys. Chem. 213 (1999) 59-65.

5) B. Tryba, A. W. Morawski and M. Inagaki, Appl. Catal. B Environ. 41 (2003) 427-433.

6) M. Toyoda, Y. Nanbu, T. Kito, M. Hirano and M. Inagaki, Desalination, 159 (2003) 273-282.

7) T. Tsumura, N. Kojitani, I. Izumi, N. Iwashita, M. Toyoda and M. Inagaki, J. Mater. Chem. 12 (2002) 1391-96.

8) T. Tsumura, N. Kojitani, H. Umemura, M. Toyoda and M. Inagaki, Appl. Surface Sci. 196 [1-4] (2002) 429-436.

9) M. Inagaki, Y. Hirose, T. Matsunaga, T. Tsumura and M. Toyoda, Carbon 41 (2003) 2619-24.

10) M. Toyoda, T. Tsumura, A. nanbu M. Omura and M. Inagaki, Mizukannkyou Gakkaishi 26 [4] (2003) 209-214.

11) B. Tryba, T. Tsumura, M. Junas, A. W. Morawski and M. Inagaki, Appl. Cataly. B: Eviron. 50 (2004) 177-83.

12) B. Tryba, A. W. Morawski, T. Tsumura, M. Toyoda and M. Inagaki, $J$. Photochem. Photobio. A: Chem. 167 (2004) 127-135.

13) M. Toyoda, Y. Yoshikawa, T. Tsumura and M. Inagaki, J. Photochem. Photobio, A: Chem. 171 (2005) 167-71.

14) M. Inagaki, F. Kojin, B. Tryba and M. Toyoda, Carbon 43 (2005) 1652-1659.

15) M. Inagaki, T. Matsunaga, T. Tsumura and M. Toyoda, TANSO 2005 [No. 219] 217-220 (2005) [in Japanese].

16) M. Toyoda, B. Tryba, F. Kojin, S. Mozia, T. Tsumura, E. Itoh and M. Inagaki, TANSO 2005 [No.220] (2005) 289-299.

17) T. Matsunaga and M. Inagaki, Appl. Cataly. B: Environ. 64 (2006) 9-12.

18) M. Inagaki, M. Nonaka, F. Kojin, T. Tsumura and M. Toyoda, Environ. Tech. 27 (2006) 521-528.

19) B. Tryba, A. W. Morawski, M. Inagaki and M. Toyoda, J. Photochem. Photobio A: Chem. 179 (2006) 224-228.
20) T. Tsumura, Y. Hattori, K. Kaneko, M. Inagaki and M. Toyoda, Desalination 169 (2004) 269-275.

21) M. Toyoda, T. Yano, S. Mozia T. Tasumura, E. Ito and M. Inagaki, TANSO 2005 (2005) 265-269.

22) M. Toyoda, T. Yano, T. Tsumura, Y. Amao and M. Inagaki, J. Adv. Oxid. Technol. 9 (2006) 49-52.

23) F. Kojin, M. Mori, T. Morishita and M. Inagaki, Chem. Lett. 35 (2006) 388-389.

24) F. Kojin, M. Mori, Y. Noda and M. Inagaki, Appl. Catal. B: Environ. (submitted).

25) M. Inagaki, S. Kobayashi, F. Kojin, N. Tanaka, T. Morishita and B. Tryba, Carbon 42 (2004) 3153-3158.

26) T. Morishita, R. Suzuki, T. Nishikawa, T. Tsumura and M. Inagaki, TANSO 2005 [No.219] (2005) 226-231.

27) T. Morishita, R. Suzuki, T. Tsumura, H. Habazaki and M. Inagaki, TANSO 2006 [No.223] (2006) 220-226.

28) T. Morishita, Y. Soneda, T. Tsumura and M. Inagaki, Carbon (in press).

29) T. Morishita, K. Ishihara and M. Inagaki, Carbon (submitted).

30) T. Morishita, K. Ishihara, M. Kato, T. Tsumura and M. Inagaki, TANSO (submitted).

31) M. Inagaki, R. Nagasaka, T. Tsumura and S. Takeuchi, J. Ceram. Soc. Japan, Supplement 112 [5] (2004) S1509-12.

32) H. Konno, H. Miura, K. Oyamada and M. Inagaki, ATB Metallurgie 37 [2-4] (1997) 149-152.

33) H. Konno, K. Oyamada and M. Inagaki, J. Europ. Ceram. Soc. 20 (2000) 1391-1396.

34) H. Konno, S. Sato, H. Habazaki and M. Inagaki, Carbon 42 (2004) 2756-2759.

35) H. Habazaki, M. Hayashi, H. Konno and M. Inagaki, Hyomen Gijutsu 56 (2005) 352-353.

36) M. Inagaki, Y. Okada, H. Miura and H. Konno, Carbon 37 (1999) 329-334.

37) M. Inagaki, K. Fujita, Y. Takeuchi, K. Oshida, H. Iwata and H. Konno, Carbon 39 (2001) 21-929.

38) M. Inagaki, T. Imase, H. Iwata, K. Fujita and H. Konno, TANSO 2002 (2002) 12-15.

39) H. Konno, K. Fujita, H. Habazaki and M. Inagaki, TANSO 2002 (2002) 113-116.

40) T. Morishita, M. Hirabayashi, Y. Nishioka, T. Okuni, N. Ota and M. Inagaki, J. Power Sources (in press).

41) M. Inagaki, T. Morishita and T. Tsumura, "New Development in Carbon Materials Science" (in press) [in Japanese]. 